\title{
Crowding honeybee colonies in apiaries can increase their vulnerability to the deadly ectoparasite Varroa destructor
}

\author{
Thomas D. SeELEy, Michael L. SMith \\ Department of Neurobiology and Behavior, Cornell University, Ithaca, NY, USA \\ Received 12 August 2014 - Revised 20 February 2015 - Accepted 9 March 2015
}

\begin{abstract}
When humans switched from hunting honeybee colonies living scattered in the wild to keeping them in hives crowded in apiaries, they may have greatly increased disease transmission between colonies. The effects of clustering colonies were studied. Two groups of 12 colonies, with hives crowded or dispersed, were established in a common environment and left untreated for mites. Drones made many homing errors in the crowded group, but not in the dispersed group. In early summer, in both groups, the colonies that did not swarm developed high mite counts, but the colonies that swarmed maintained low mite counts. In late summer, in the crowded group but not in the dispersed group, the colonies that swarmed also developed high mite counts. All colonies with high mite counts in late summer died over winter; all colonies with low mite counts in late summer survived over winter. Evidently, swarming can reduce a colony's mite load, but when colonies are crowded in apiaries, this mite-load reduction is erased as mites are spread through drifting and robbing.
\end{abstract}

apiary / Apis mellifera / crowding / drifting / evolutionary trap / parasitism / Varroa destructor

\section{INTRODUCTION}

The history of human exploitation of honeybees (Apis mellifera) for their wax and honey includes a major transition that occurred when humans switched from hunting for colonies living in natural cavities to keeping colonies in purposemade hives. The earliest known shift from bee hunting to beekeeping occurred in ancient Egypt around $2400 \mathrm{BC}$ when people started hiving honeybees in horizontal cylinders made of fired clay or sun-dried mud (Crane 1999, p. 161). A second origin of hiving honeybees occurred in northern Europe around AD 200, when people began keeping these bees in hollow logs (in the deciduous forest zone) or inverted baskets (west of the forest zone) (Crane 1999, pp. 226 and 238). Each time it happened, the switch to keeping honeybees in

Corresponding author: T. Seeley, tds5@cornell.edu Manuscript editor: Peter Rosenkranz hives set the stage for a fundamental change in the ecology of these bees because it enabled people to crowd honeybee colonies into apiaries. The effect on colony spacing was huge, because up to this time the colonies living in European forests nested in tree cavities spaced $100 \mathrm{~s}$ of meters apart. In medieval Russia, for example, the honeybees inhabiting trees in the forests around the city of Nizhny Novgorod had a density of 1-2 colonies per $\mathrm{km}^{2}$ (Galton 1971), hence they were spaced, on average, 700-1,000 m apart. Similarly, in the USA today, the honeybee colonies nesting in tree cavities in the forests around Ithaca, New York have a density of approximately 1 colony per $\mathrm{km}^{2}$ and a mean nearest-neighbor distance of $850 \mathrm{~m}$ (see maps in Seeley 2007; Seeley et al. 2015). In contrast, the honeybees residing in hives in apiaries around the world have nearest-neighbor distances that are often only about $1 \mathrm{~m}$ (see photos of apiaries in Crane 1983, 1999).

The clustering of honeybee colonies in apiaries is certainly advantageous for humans because it makes beekeeping practical, but it is not beneficial 
for bees. Relative to colonies living in widely dispersed nests, colonies living in hives clustered in apiaries can experience greater competition for forage (Crane 1990, p. 194), a higher risk of having their honey stolen by bees from other colonies when nectar is in shortage (Free 1954; Downs and Ratnieks 2000), and more problems in reproduction, for example, the loss of queens that return to hives other than their own on their mating flights (Crane 1990, p. 196). Perhaps, though, the greatest disadvantage experienced by honeybee colonies living jam-packed in an apiary is the elevated risk of acquiring pathogens and parasites from neighboring colonies. This can happen whenever beekeepers move combs bearing bees and brood between colonies within an apiary. Consequently, beekeepers have developed "hive quarantine" management techniques for controlling certain diseases (e.g., American foul brood; see Goodwin and Van Eaton 1999). But perhaps the most common mechanism of disease transmission between colonies within an apiary is "drifting", that is, adult bees accidentally returning to the wrong hive (Free 1958). The frequency of this mistake depends on how the hives are arranged in the apiary, and can be greatly reduced by increasing their spacing, painting them different colors, and having them face different directions (Jay 1965, 1966b; Pfeiffer and Crailsheim 1998). However, in the common situation of hives arranged in a row, spaced about one meter, painted the same color, and facing the same direction, it is common for $40 \%$ or more of all worker bees to drift from their natal colony to a neighboring colony (Jay 1965, 1966a, b).

This study examined the effects of aggregating honeybee colonies in apiaries on the spread of the ectoparasitic mite Varroa destructor. This mite, which acts as a vector of viruses infecting honeybees (Gisder et al. 2009), has boosted the prevalence and virulence of certain viruses and has caused the deaths of millions of honeybee colonies worldwide in recent years (Martin et al. 2012). V. destructor has two distinct life stages: a phoretic phase spent on adult bees and a reproductive phase spent in a brood cell (Rosenkranz et al. 2010). During the phoretic phase, Varroa mites are generally found between the abdominal segments of adult bees (workers and drones), so when bees drift between colonies, they spread both the phoretic mites and the viruses. Given that Varroa mites can be spread between honeybee colonies through drifting, we hypothesized that a population explosion of mites in one colony will easily spread among crowded colonies but not among dispersed ones. This hypothesis was tested experimentally over a 2-year period by establishing in a common environment two groups of 12 colonies, one with the hives crowded and one with them dispersed. None of the 24 colonies received mite control treatments over the 2-year study period. We measured the drifting of drones between the colonies, monitored the Varroa mite populations within the colonies, kept track of when the colonies swarmed, and noted when colonies died.

\section{MATERIALS AND METHODS}

\subsection{Study site and experimental layout}

This study was conducted at the Zeman Laboratory for Radar Interferometer Studies of the School of Electrical and Computer Engineering at Cornell University, near Ithaca, New York State, USA $\left(42.495489^{\circ} \mathrm{N}, 76.431198^{\circ} \mathrm{W}\right)$. Behind the laboratory building is a 20-ha area that once was farmland but now is covered with trees and shrubs and a beaver pond, except for one long and narrow $(270 \times 10 \mathrm{~m})$ field that was kept open for a large antenna. The antenna was removed in 2007, but the field was maintained by mowing. Near the laboratory building, a group of crowded colonies was established in an apiary with 12 hives. These hives were arranged in a row in pairs separated by ca. $1 \mathrm{~m}$, and with their entrances facing south, a layout that is typical for an apiary (see Figure 1). In and around the nearby field, a group of dispersed colonies was established in an array with 12 more hives. Two of these hives were placed in the field and 10 were placed in small clearings along the north and south sides of this field. These 12 hives were spaced 21-73 m apart (nearest-neighbor distances, $33.7 \pm 14.6 \mathrm{~m}$; mean $\pm \mathrm{SD}$ ) and with their entrances facing south (see Figure 2). 


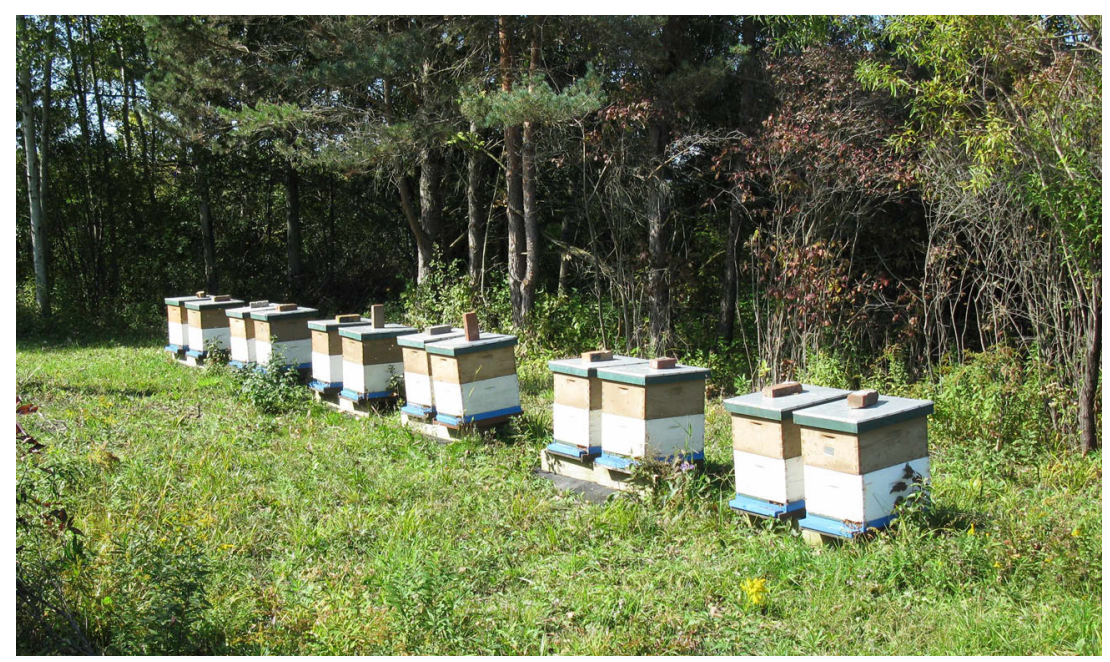

Figure 1. The 12 crowded colonies arranged in the apiary.

\subsection{Establishing study colonies}

In both groups of colonies (crowded and dispersed), there were 10 colonies that were headed by Golden Italian queens purchased from Olivarez Honey Bees, Chico, California, and 2 colonies that were headed by New World Carniolan queens purchased from Strachan Apiaries, Yuba City, California. All 24 queens were reared in April/May 2011, and all were naturally mated. We used these two types of queens in the study colonies so that we could measure the level of drifting by drones within the two groups. The Golden Italian queens were homozygous for the recessive allele "cordovan" (hence their golden color), so all the drones produced in their colonies were bright yellow (note the following: not all the worker offspring of the Golden Italian queens' were bright yellow, because these queens were open mated and so received some sperm from drones not carrying the cordovan allele.) The New World Carniolan queens had wild-type (dark brown) bodies, and all the drones produced in their colonies were dark brown or black.

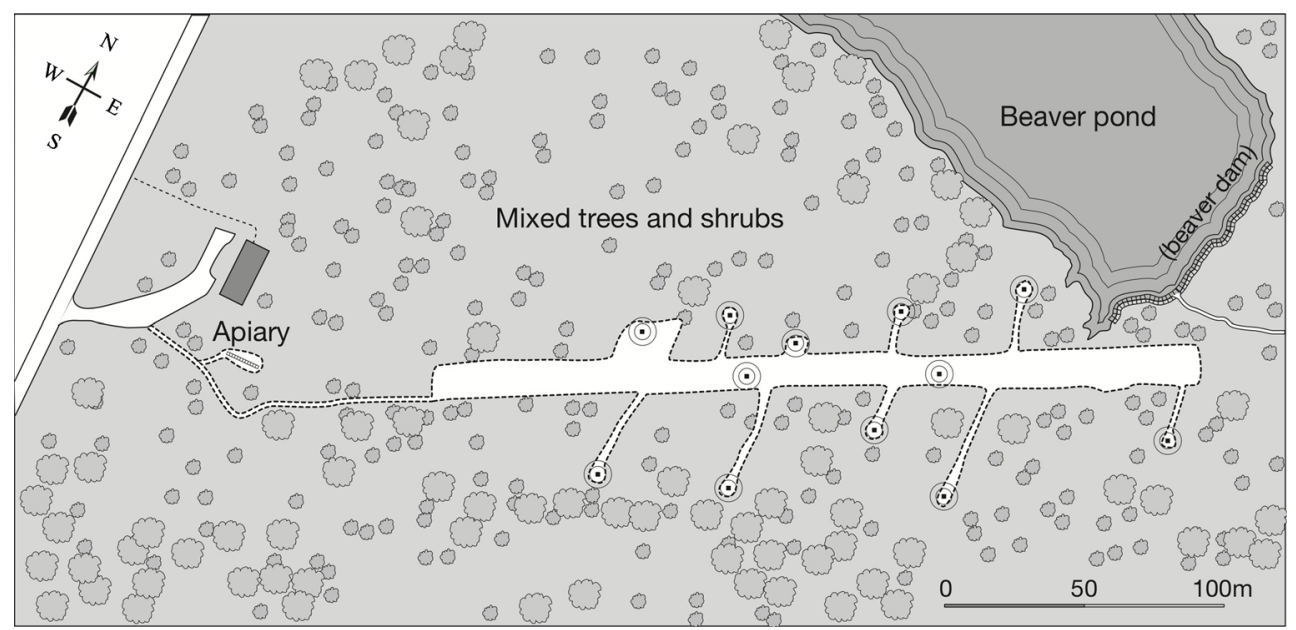

Figure 2. Map of the study site showing the locations of the 24 study colonies: 12 hives of bees in the apiary (indicated by the row of white squares ) and 12 hives of bees in and around the field (indicated by the black squares surrounded by circles ). 
The 24 study colonies were established on 25 May 2011 when 24 "nucleus colonies" were prepared using frames of bees and brood taken from stock colonies of Cornell University. Each nucleus colony consisted of two frames of adult bees and brood, two frames of honey and pollen, and one frame of empty comb, all installed in a five-frame hive. All the frames were standard Langstroth frames $(48 \times 23 \mathrm{~cm})$. The 24 study colonies were prepared as 12 matched pairs, in which the bees, brood, and food for the two colonies in each pair came from the same stock colony. As a result of these measures, the 24 study colonies started out matched in size and level of mite infestation (ca. six mites caught on sticky board in $48 \mathrm{~h}$; see Results). Within each treatment group (crowded or dispersed), the two colonies headed by New World Carniolan queens were positioned at the center of the group: in the crowded group, positions 6 and 8 in the row of hives (the two hives in Figure 1with bricks on top oriented vertically); and in the dispersed group, the two hive locations in the long field. The five-frame hives were painted different colors to minimize drifting of the bees at first.

On 6 June 2011, the 24 study colonies were transferred from their five-frame hives to standard 10-frame Langstroth hives, and each colony was given five more frames of comb, all empty. All 24 hives were the same color and had entrances of the same size $(10.0 \times 2.2 \mathrm{~cm})$ and in the same position (see Figure 1). A "wood bound Varroa screen" (Dadant and Sons, Hamilton, Illinois, USA) was installed between the hive body and the bottom board of each hive so the number of mites dropping from each hive could be counted easily. Because mites reproduce preferentially in cells of drone brood (Fuchs 1990) and have a higher reproductive rate on drone brood than on worker brood (ca. 2.20 vs. 1.45 female offspring per mite, respectively (Martin 1994, 1995), it was important that each hive contained the same amount of drone comb (i.e., comb built of the large cells in which drones are reared). To achieve this, one frame of empty drone comb was installed in each hive (in frame position no. 8) and the other nine frames of comb in each hive were carefully chosen to contain minimal drone comb $\left(<20 \mathrm{~cm}^{2}\right.$ per frame). When each study colony was installed in its 10 -frame hive, its queen was located and labeled with a dot of yellow paint so we could detect replacements of the original queens in our colonies. Only one queen was replaced by the bees during the first summer: in June 2011, in one colony in the dispersed group that started out with a cordovan queen, the workers replaced this queen with a wild-type queen, and then in July, they replaced their replacement queen. Consequently, this colony had ceased producing cordovan (bright yellow) drones by summer's end in 2011.

On 15 July 2011, each colony was given a second full-size ("deep"), 10-frame hive body that contained 9 frames of empty worker comb and 1 frame of empty drone comb, again with the frame of drone comb in position no. 8, and each frame of worker comb containing $<20 \mathrm{~cm}^{2}$ of drone comb. All 24 hive bodies were the same color (light brown) and all were placed atop the white hive body that was already in place. This completed the set up of the hives for this experiment; the colonies received no further expansions of their hives.

Of the 24 study colonies that were established in May 2011, 22 were strong in September 2011 and all of these colonies survived until the following summer. The two colonies that were not strong in late 2011 were a pair of colonies that had been established using bees and brood from the same stock colony. The brood that they received was infected with the fungus Ascosphaera apis, which causes the disease chalkbrood; consequently, these two colonies never grew to full strength, never produced drones, and eventually died during the winter of 2011-2012.

None of the colonies was treated for Varroa mites during the two years of the experiment: June 2011 to May 2013.

\subsection{Measuring drone drifting}

The intensity of drifting by drones among colonies in the crowded and dispersed groups was measured twice, on the afternoons of 12 September 2011 and 30 April 2012. Both days, the weather was warm and sunny, ideal for drones to conduct mating flights. To measure drone drifting, counts were made of the number of cordovan (bright yellow) and wild-type (dark brown) drones returning to each of our study colonies, except the two colonies that were greatly weakened by chalkbrood infections and so contained no drones in September 2011 and were dead in April 2012. On both sampling dates, each colony was watched until at least 100 homecoming drones had been recorded; the average number was 143 drones. Data were collected just twice because both the fall and spring data revealed a large and consistent difference between the crowded 
and dispersed colonies in level of drone drifting. The intensity of drifting by workers was not measured because the colonies headed by the open-mated Cordovan queens produced a mixture of bright yellow and dark brown workers, which made it impossible to get accurate measurements of the drifting by workers.

\subsection{Measuring mite drop, mite infestation, and checking for swarming}

Monitoring natural mite drop is one of the standard methods for determining the number of Varroa mites in a colony (Branco et al. 2006), though mite drop counts must be interpreted carefully because they are a function of colony size and brood number, as well as the level of infestation (mites per adult worker). The number of mites that dropped from each colony onto a gridded sticky board beneath a "Varroa screen" was measured once a month during a 48-h period. In 2011, mite drop counts were made mid-month in June, July, August, and September. In 2012, mite drop counts were made at month's end in April, May, June, July, and August. Starting in late June 2012, by which time some of the colonies had swarmed, so there was great variation in colony size, measurements of mite infestation were also made using the powdered sugar method (see Branco et al. 2006) to determine the number of phoretic Varroa mites per 300 bees in each colony.

Each colony was inspected monthly to see if it had swarmed and to estimate its size (number of frames containing at least $100 \mathrm{~cm}^{2}$ of brood). A colony was judged to have swarmed if it contained emerged queen cells or an unmarked queen, and it showed a break in brood production. None of the colonies swarmed in 2011 because they all started out as small colonies. In 2012, many, but not all, of the colonies swarmed. None of the swarms were captured.

\subsection{Statistical tests}

All descriptive statistics are reported as the mean \pm 1 SD. In the study of drone drifting, we used two MannWhitey $U$ tests (one each for the 2011 and the 2012 results; we applied a Bonferroni correction, with $\alpha=0.025$, rather than 0.05 ) to test for a difference between colonies that produced cordovan and wild-type drones in the proportion of cordovan drones returning to their hives. In the study of Varroa population dynamics, we used Student's $t$ tests (two-tailed) to test for differences between the two treatment groups (e.g., crowded and dispersed colonies) in the mean number of mites caught on a sticky board over $48 \mathrm{~h}$, the number of mites per 300 worker bees, or the number of frames containing brood. We performed a repeated series of statistical tests of the Varroa counts (one for each monthly data set), rather than a single repeatedmeasures test, so we could tell for each month whether or not there was a significant difference in Varroa level between colonies in the two treatment groups. To avoid spurious positive outcomes from the four (in 2011) or five (in 2012) repeated tests of the mite drop counts each summer, we applied a Bonferroni correction, with $\alpha=0.005$, rather than 0.05 ). We used a twotailed Fisher's exact probability test to test for an association between colony spacing (crowded or dispersed) and colony survival (dead or alive) over the second winter of the experiment.

\section{RESULTS}

\subsection{Effect of colony spacing on drone drifting}

Figure 3 depicts the results of our measurements of drifting by drones between colonies. Looking first at the results for the dispersed colonies, we see that in both September 2011 and April 2012, the drones entering the hives with cordovan queens were $100 \%$ cordovan drones, and the drones entering the hives with wild-type queens were only $0-6 \%$ cordovan drones (hence were nearly $100 \%$ wild-type drones). For both sampling times, the difference in proportion of cordovan drones entering the two types of hive (with cordovan or wild-type queen) is highly significant [Mann-Whitney $U$ test, $U(8,3)=54$, $P<0.001$ (September 2011); $U(8,3)=54$, $P<0.001$ (April 2012)].

Turning to the results for the crowded colonies, we see a strikingly different pattern. In both September 2011 and April 2012, the drones entering the hives with cordovan queens were, on average, only 65 and $58 \%$ cordovan drones, and the drones entering the hives with wild-type queens were, on average, 48 and $44 \%$ cordovan drones (hence were only 52-56\% wild-type drones). For both sampling times, the difference in proportion of cordovan drones entering the two 

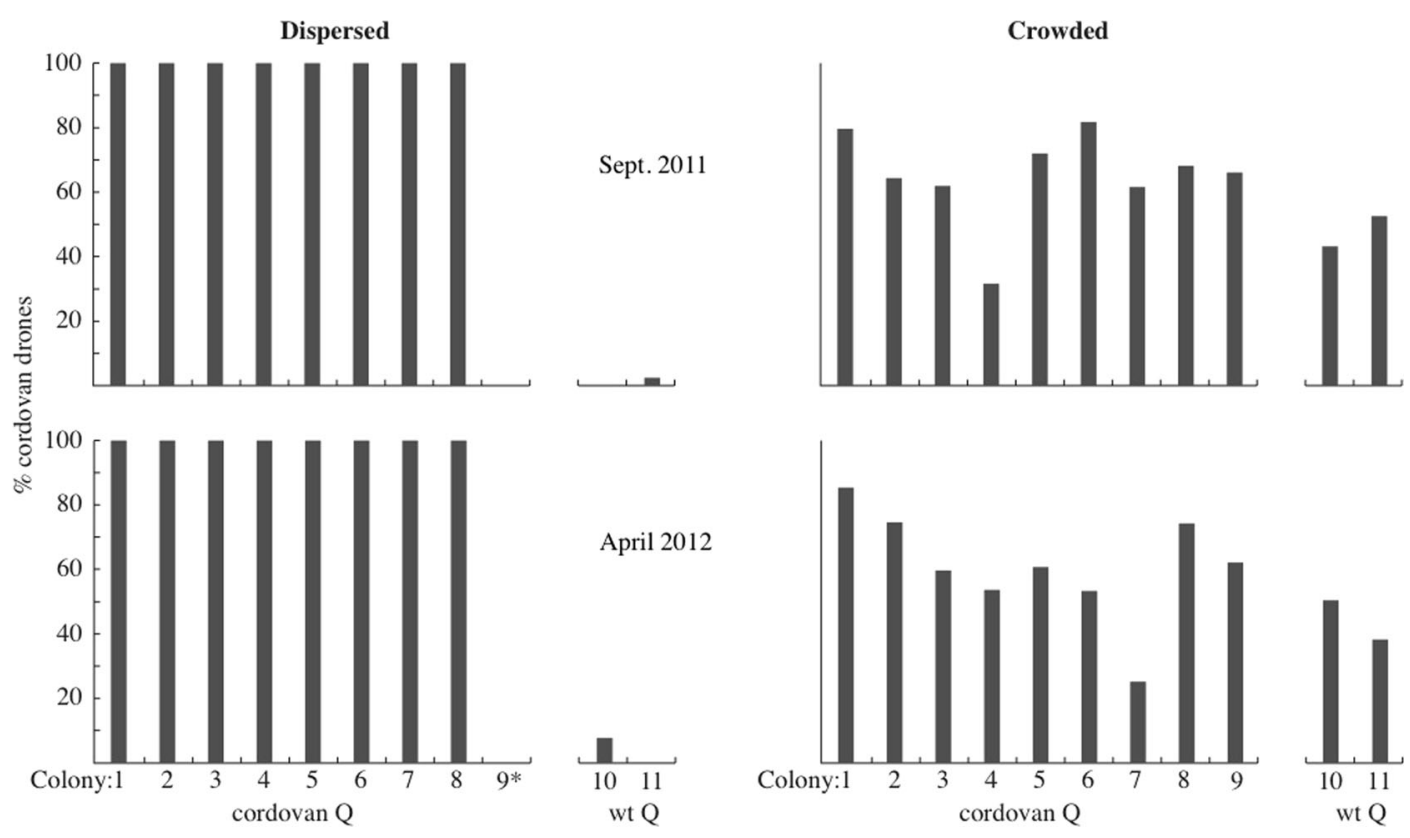

Figure 3. The percentage of cordovan (bright yellow) drones entering each hive in the two groups, dispersed and crowded. In both groups, colonies 1-9 were given cordovan queens so they produced bright-yellow drones, and colonies 10 and 11 were given wild-type queens (wt Q) so they produced dark-brown drones (in the dispersed group, however, the bees in colony $9 *$ replaced their cordovan queen with a wild-type queen, so this colony also produced wild-type drones.) Deviations from $100 \%$ cordovan drones for the cordovan-queen colonies or $0 \%$ cordovan drones for the wild-type-queen colonies indicate drifting of drones between colonies.

types of hive is not significant [Mann-Whitney $U$ test, $U(9,2)=16, P=0.10$ (Sept. 2011); $U(9$, 2) $=15, P=0.20$ (April 2012)].

\subsection{Effect of colony spacing on Varroa population dynamics}

In the summer of 2011, the 12 colonies in both treatment groups grew steadily, none of them swarmed, and the mean mite drop counts for the two groups (crowded vs. dispersed) did not diverge: June, $6.8 \pm 10.9$ mites vs. $6.3 \pm 9.2$ mites, $t_{22}=0.11, P=0.92 ; J u l y, 5.7 \pm 11.8$ mites vs. 4.8 \pm 9.5 mites, $t_{22}=0.19, P=0.88$; August, 12.2 \pm 22.1 mites vs. $6.7 \pm 7.4$ mites, $t_{22}=0.75$, $P=0.23$; September, $31.7 \pm 29.5$ mites vs. 28.3 \pm 12.2 mites, $t_{22}=0.36, P=0.72$. Thus, the two groups of colonies started out with essentially the same low number of mites per colony, and they stayed matched in this regard throughout the first summer, though the number of mites per colony increased greatly over this summer. In mid-September, 2011, all of the colonies were strong (except the pair that had severe chalkbrood (A. apis) infections); workers covered $16+$ of the 20 combs, and the combs in the top hive body were stuffed with honey.

In the summer of 2012, the two groups of colonies started out still closely matched. At this point, both groups consisted of 11 colonies, because each group had lost one colony that had been weakened by a fungal infection ("chalkbrood") and had died over winter. All 11 remaining colonies in both groups started out in good condition, with at least 3 combs containing brood in late April. Moreover, the two groups of colonies began the summer with similar mite drop counts, though already the crowded colonies were showing signs of having higher mite populations, with slightly higher mite drop counts in late April and late May (crowded vs. dispersed): April, 20.6 \pm 11.6 mites vs. $13.0 \pm 10.2$ mites, $t_{20}=1.64, P=0.12$; 
May, $154.3 \pm 83.7$ mites vs. $109.4 \pm 74.4$ mites, $t_{20}=1.52, P=0.15$. At these two sampling times, the two groups of colonies were also still nicely matched in size, measured by number of frames of comb containing brood (crowded vs. dispersed): April, 4.7 \pm 1.7 frames vs. 5.0 \pm 1.2 frames, $t_{20}=0.47, P=0.64 ;$ May, $8.7 \pm 4.0$ frames vs. 8.4 \pm 4.0 frames, $t_{20}=0.13, P=0.90$.

Starting in June, however, when 7 of the 11 colonies in each group swarmed, there developed striking differences in the Varroa mite drop counts among the colonies in both the crowded and dispersed groups. To understand these differences, it helps to divide the 11 colonies in each group into three subgroups, as shown in Figure 4: colonies that did not swarm (4 colonies in each group), colonies that swarmed and managed to requeen ( 2 colonies in the crowded group and 5 colonies in the dispersed group), and colonies that swarmed but failed to requeen ( 5 colonies in the crowded group and 2 colonies in the dispersed group). There was a suggestive, but not significant, difference in probability of requeening failure between the colonies that swarmed in the crowded group (5 out of 7) and the colonies that swarmed in the dispersed group (2 out of 7): two-tailed Fisher exact probability test, $P=0.28$. Each of the seven colonies that swarmed but failed to requeen was essentially dead (had zero frames of brood) by late July; so the last mite drop counts for these colonies were made at the end of June.

Regarding the 15 queenright colonies total for both the crowded and dispersed groups, we see in
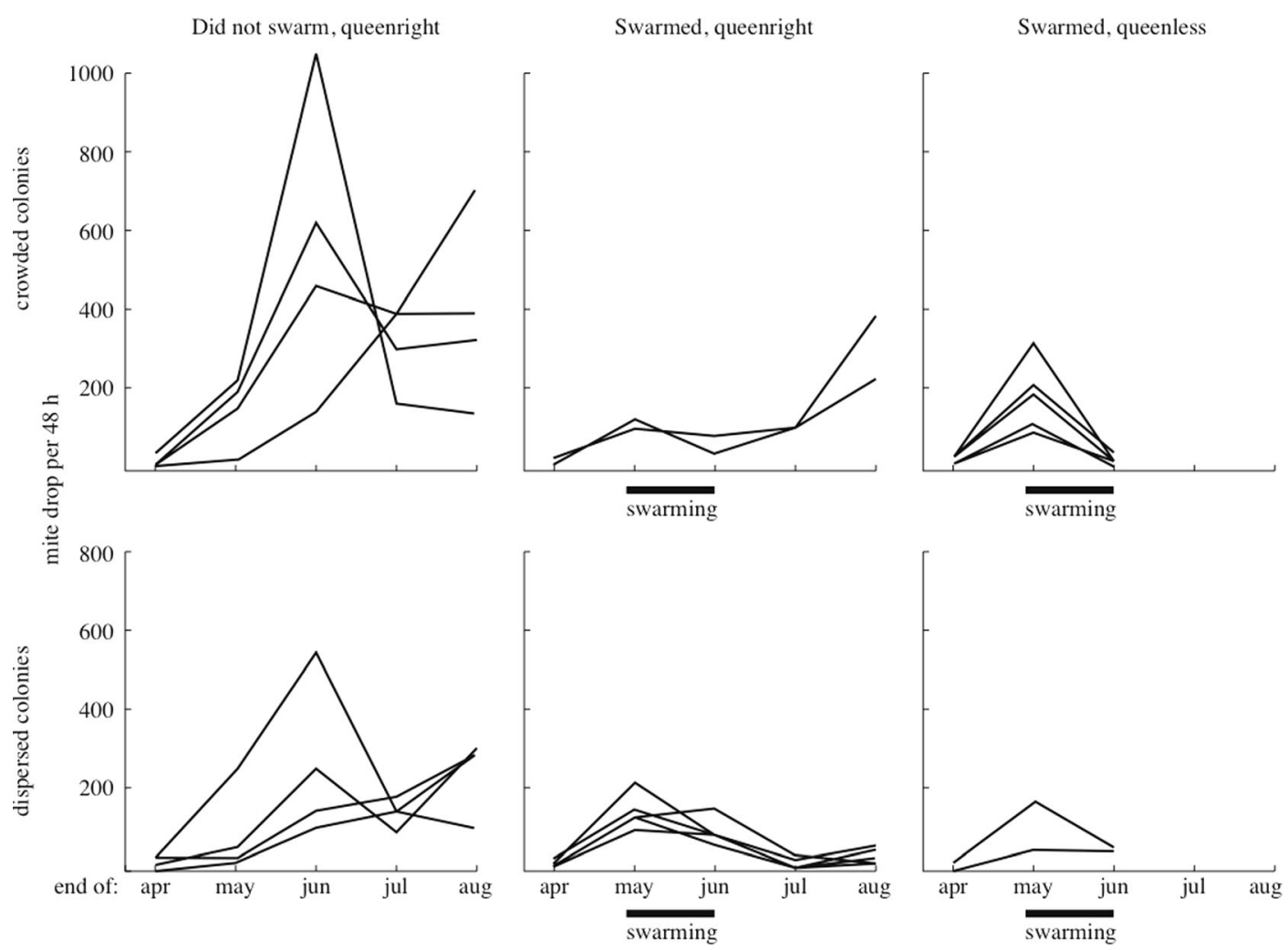

Figure 4. Dynamics of the Varroa mite populations over the summer of 2012 for the 11 crowded colonies and the 11 dispersed colonies, as measured by natural mite drop counts (for additional data on the adult mite infestations, see text). Each group of 11 colonies was divided into three subgroups defined by whether the colony did or did not swarm, and by whether the colony did or did not possess a fertile queen (i.e., was "queenright" or "queenless"). Bars labeled "swarming" specify the period during which all swarming occurred. 
Figure 4 that the swarming activity in June gave rise to a marked difference in the mite drop counts between the colonies that did not and did swarm. Before swarming, the eight colonies that did not swarm and the seven colonies that did swarm had essentially identical mite drop counts (did not vs. did): late April, $18.1 \pm 13.3$ mites vs. 12.0 \pm 7.9 mites, $t_{13}=1.07, P=0.34$; late May, $117.9 \pm 96.7$ mites vs. $135.4 \pm 38.7$ mites, $t_{13}=0.45, P=0.64$. After swarming in June, however, the eight colonies that did not swarm and the seven colonies that did swarm had strikingly different mite drop counts (did not vs. did): late June, 414.1 \pm 320.6 mites vs. $85.3 \pm 35.4$ mites, $t_{13}=2.69, P=0.02$; late July, $226.0 \pm 123.1$ mites vs. $39.3 \pm 43.9$ mites, $t_{13}=3.79, P=0.005$. To see if the colonies that swarmed had lower mite drop counts simply because they had fewer workers and less brood relative to the colonies that did not swarm, we made measurements of the mites/300 bees in late June, July, and August. We found that the colonies that did not and did swarm showed clear differences in this additional measure of mite infestation (did not vs. did): late June, 18.5 $\pm 16.4 \mathrm{mites} / 300$ bees vs. $2.9 \pm 2.6 \mathrm{mites} / 300$ bees, $t_{13}=2.49, P=0.03$; late July, 24.6 \pm 5.2 mites $/ 300$ bees vs. $4.0 \pm 1.8$ mites $/ 300$ bees, $t_{13}=9.64, P=0.0001$.

The most surprising result of this experiment, however, is the difference in the mite drop counts that emerged at the end of the summer in the queenright colonies that had swarmed, between the crowded vs. the dispersed groups . Curiously, the mite drop counts became high again in the two colonies in the crowded group that swarmed and requeened, but the mite drop counts stayed low in all five colonies in the dispersed group that swarmed and requeened (crowded vs. dispersed): late July, $102.5 \pm 0.7$ mites vs. $14.0 \pm 9.5$ mites, $t_{5}=12.42, P<0.001$; late August, $306 \pm 113$ mites vs. $38 \pm 22$ mites, $t_{5}=5.91, P=0.005$. The measurements of mites $/ 300$ bees revealed no difference in the queenright colonies that had swarmed between the crowded vs. the dispersed groups in late July (crowded vs. dispersed: $5.0 \pm 1.4$ mites/ 300 bees vs. $3.4 \pm 1.5$ mites $/ 300$ bees, $t_{5}=1.31$, $P=0.26$ ) but a marked difference in late August (crowded vs. dispersed: $11.5 \pm 2.1 \mathrm{mites} / 300$ bees vs. $1.6 \pm 1.5$ mites $/ 300$ bees, $t_{5}=7.15, P=0.0008$ ).

\subsection{Effect of colony spacing on colony mortality}

In late August 2012, all eight colonies that had not swarmed - and had extremely high mite drop counts-looked unhealthy. Their populations were shrinking and they contained workers with deformed wings. In contrast, all of the colonies that had swarmed looked healthy, with large populations of worker bees, none with deformed wings. By mid December 2012, all eight colonies that had not swarmed were dead, as were the two colonies in the crowded group that had swarmed (and had developed high mite levels in late summer). Only the five colonies in the dispersed group that had swarmed (and still had low mite levels in late summer) survived the winter. In late April 2013, these five colonies were all in good condition and had low mite drop counts $(10.8 \pm 7.7$ mites) and low levels of mite infestation $(1.4 \pm 1.5$ mites/300 bees). Therefore, among the 15 colonies that were alive in late August 2012, there was a marked difference in winter survival between the colonies in the crowded group ( 0 out of 6 ) and those in the dispersed group (5 out of 9): twotailed Fisher exact probability test, $P=0.029$.

\section{DISCUSSION}

This study shows that the crowding of honeybee colonies in an apiary can boost the drifting of drones between colonies. It also suggests that this crowding can lead to healthy colonies suddenly acquiring lethal infestations of Varroa mites when other colonies in the same apiary are dying from high levels of Varroa mites and viruses. By showing that differences in colony spacing, even on a small scale (ca. $1 \mathrm{~m}$ vs. ca. $30 \mathrm{~m}$ ), can strongly influence the mite infestations of colonies, this study complements a previous study that showed that differences in colony spacing on a landscape scale (in regions with low vs. high colony densities) can strongly influence the mite infestations of colonies (Frey and Rosenkranz 2014).

In the present study, when colonies were housed in ways that are typical for apiculture - in hives painted the same color, arranged in a row and facing the same direction, and spaced tightly-it was found in both years that 
approximately $35 \%$ of the drones entering each colony's hive did not match the color morph produced by the colony. Clearly, there was a high level of drones drifting among the crowded colonies. In contrast, essentially, no drifting of drones was found among colonies in the dispersed group, which were housed in hives that were identical to those in the crowded group but were spaced more widely. The mechanisms by which a drone bee finds his way home on a mating flight have not been studied, but probably they match those used by a worker bee to orient home on a foraging flight: use of dead reckoning and perhaps a cognitive map to return to the correct general area (Wehner 1992; Menzel et al. 2012) and then use of snapshot memories of local landmarks (Collett and Graham 2004) and possibly use of social cues (such as bee flight traffic) to pinpoint the hive entrance. It now seems clear that when we humans house bees in identical hives placed close together and facing the same direction, we create an "evolutionary trap" for the bees, that is, an environment in which the physical and social cues that an animal uses to solve a problem are altered, rendering the animal prone to make decision errors (Schlaepfer et al. 2002). Specifically, when honeybees live in an apiary with identical hives arranged in rows and spaced close together, the bees no longer inhabit an environment of evolutionary adaptedness (Symons 1990) and they make maladaptive homing decisions. Our study shows that drone bees living in a crowded apiary will make many homing errors. Other studies have shown already that worker bees living in crowded apiaries also make many homing errors (Jay 1965; 1966a; b; Pfeiffer and Crailsheim 1998). Both drone and worker homing errors provide a means for Varroa mites to spread between colonies. Future work is needed to measure the rate of mite spread via drifting drones and workers.

This study also shows that swarming can strongly affect the infestation levels of Varroa mites in colonies in apiaries, and therefore the survival of these colonies. In both the crowded and dispersed groups of colonies, it was found that the colonies that did not swarm and those that did swarm started the summer of 2012 with similar mite drop counts. It was also found in both groups that once the colonies that swarmed did so, their 48-h mite drop counts and their counts of mites/ 300 bees fell to $15-20 \%$ of the level of the counts for the colonies that did not swarm. It seems likely that the mite infestation levels dropped markedly in the colonies that swarmed because when a colony casts a swarm, it loses $40-70 \%$ of its worker bee population (Wilde et al. 2005; Rangel and Seeley 2012), and since approximately $50 \%$ of the mites in a colony are on the adult bees (Fuchs 1985), this means that a colony loses $20-35 \%$ of its adult mites each time it swarms (as shown by Wilde et al. 2005). Furthermore, because a swarming colony can cast multiple swarms - one "prime swarm" and sometimes several "afterswarms" (Gilley and Tarpy 2005) - swarming can greatly reduce a colony's mite population. Besides quickly exporting many mites from a colony, swarming might also lead to a more protracted process of mite removal because swarming creates a period lasting 1-3 weeks when there is no sealed brood in a colony. This period without sealed brood arises because whenever a colony swarms, and the mother queen leaves, it takes the replacement queen 1-3 weeks to emerge as an adult, kill her rivals, get mated, and begin laying eggs. During this period without sealed (pupal) brood, the mites can neither reproduce nor hide in cells containing pupae; consequently, they will suffer a decreased birth rate, and they may also suffer an increased mortality rate, being vulnerable to getting bitten by bees and groomed off them (Arechavaleta-Velasco and Guzmán-Novoa 2001).

A previous two-year study of the effect of swarming on Varroa mite populations in colonies not treated for mites (Fries et al. 2003) also found markedly lower Varroa mite drop counts and infestation levels (mites per worker bee) in swarming colonies relative to non-swarming colonies, but only in the first of two summers. This may be because all the colonies in this previous study were crowded in apiaries, so when the mite populations in the study colonies grew to high levels in the second summer (see Figure 4 in Fries et al. 2003), there may have been much spreading of the mites from highly infected to less infected colonies, like what was observed among the crowded colonies in the second summer of the present study. 
Perhaps the most important result of the present study is the finding that the low mite infestations seen in early summer (late June) in every colony that swarmed and requeened itself persisted in the colonies in the dispersed group but not in the crowded group. In the crowded group, the colonies that swarmed and requeened showed rising mite infestations in late July, and by the end of August, their mite drop counts and their counts of mites/300 bees were as high as those in the colonies that did not swarm. It is likely that the high levels of Varroa infestation in the two colonies (in the crowded group) that did swarm, and in the eight colonies (in the crowded and dispersed groups) that did not swarm, shortened the lifespans of the "winter bees" that were produced at the end of the summer (van Dooremalen et al. 2012). This would explain why all ten colonies that had high mite drop counts (and high counts of mites/300 bees) in late August were dead by December while at the same time all five colonies that had low mite drop counts (and low counts of mites/300 bees) in late August were alive and thriving the following April.

We cannot say for sure how the two colonies that swarmed and requeened in the crowded group developed high mite infestations in August while at the same time the five colonies that swarmed and requeened in the dispersed group did not. One possibility is that the two colonies in the crowded group acquired their numerous mites by robbing honey from the nests of the weaker, mite-infested colonies in the area (Sakofski et al. 1990; Greatti et al. 1992; Frey et al. 2011). Most years, there is a marked dearth of nectar in the Ithaca area in August. Moreover, it is now known that as the mite abundance in a colony increases, the mites are increasingly apt to climb onto foragers (not just nurse bees), including foragers from another colony that are robbing (Cervo et al. 2014). But mite dispersal via robbing cannot, by itself, explain why, of the seven colonies that swarmed and requeened themselves, only the two in the crowded group developed high mite infestations in August. Presumably, all seven colonies could have robbed other colonies in August. A second possibility is that in both the crowded and the dispersed groups, the workers and drones in the colonies that did not swarm-and so had dreadfully high mite infestations - were especially prone to drifting, and that in the crowded group, this drifting occurred more strongly because "receiver" colonies were more easily found, being close at hand. If this occurred, the greater drifting by bees in the highly infested colonies could have been due to deterioration of the homing abilities of the increasingly sick bees in the highly infested colonies (Kralj and Fuchs 1977) or to stronger manipulation of these bees by the numerous Varroa mites in these colonies (Hughes 2005). Goodwin et al. (2006), however, found no evidence for higher levels of drifting by bees in colonies with mites relative to those in colonies without mites, but the subject needs further study, for example, to determine what level of mite infestation, if any, gives rise to greater drifting. Whatever the precise mechanism, it now seems clear that when honeybee colonies are forced to live in identical hives that are clustered in an apiary, a high level of drifting can occur and colonies can be vulnerable to $V$. destructor and the viruses that the mites carry, especially if one or more of the clustered colonies collapses.

\section{ACKNOWLEDGMENTS}

We thank Dr. Wesley E. Swartz, School of Electrical and Computer Engineering, Cornell University, for the use of his radar array field for our study site and Sean R. Griffin for his assistance in spring 2011 in setting up the 24 colonies of bees. This research was supported by a Hatch Grant (2010-11-237) from the Cornell University Agriculture Experiment Station (to TDS), and by a US National Science Foundation Graduate Research Fellowship (to MLS).

Rassembler un grand nombre de colonies d'abeilles dans des rûchers peut accroître leur vulnérabilité à l'ecto-parasite Varroa destructor

Apis mellifera / parasitisme / surpeuplement / dérive / piège évolutif

Eine hohe Völkerdichte am Bienenstand kann deren Anfälligkeit für den gefährlichen Ektoparasiten Varroa destructor erhöhen

Bienenstand / Apis mellifera / Völkerdichte / Verflug / evolutionäre Falle / Parasitismus / Varroa destructor 


\section{REFERENCES}

Arechavaleta-Velasco, M.E., Guzmán-Novoa, E. (2001) Relative effect of four characteristics that restrain the population growth of the mite Varroa destructor in honey bee (Apis mellifera) colonies. Apidologie 32 , 157-174

Branco, M.R., Kidd, N.A.C., Pickard, R.S. (2006) A comparative evaluation of sampling methods for Varroa destructor (Acari: Varroidae) population estimation. Apidologie 37, 452-461

Cervo, R., Bruschini, C., Cappa, F., Meconcelli, S., Pieraccini, G., Pradella, D., Turillazzi, I. (2014) High Varroa mite abundance influences chemical profiles of worker bees and mite-host preferences. J. Exp. Biol. 217, 2998-3001

Collett, T.S., Graham, P. (2004) Animal navigation: path integration, visual landmarks and cognitive maps. Curr. Biol. 14, R475-R477

Crane, E. (1983) The archaeology of beekeeping. Duckworth, London

Crane, E. (1990) Bees and beekeeping. Cornell University Press, Ithaca, New York

Crane, E. (1999) The world history of beekeeping and honey hunting. Duckworth, London

Downs, S.G., Ratnieks, F.L.W. (2000) Adaptive shifts in honey bee (Apis mellifera L.) guarding behavior support predictions of the acceptance threshold model. Behav. Ecol. 11, 233-240

Free, J.B. (1954) The behaviour of robber honeybees. Behaviour 7, 233-240

Free, J.B. (1958) The drifting of honey-bees. J. Agric. Sci. 51, 294-306

Frey, E., Rosenkranz, P. (2014) Autumn invasion rates of Varroa destructor (Mesostigmata: Varroidae) into honey bee (Hymenoptera: Apidae) colonies and the resulting increase in mite populations. J. Econ. Entomol. 107, 508-515

Frey, E., Schnell, H., Rosenkranz, P. (2011) Invasion of Varroa destructor mites into mite-free honey bee colonies under the controlled conditions of a military training area. J. Apic. Res. 50, 138-144

Fries, I., Hansen, H., Imdorf, A., Rosenkranz, P. (2003) Swarming in honey bees (Apis mellifera) and Varroa destructor population development in Sweden. Apidologie 34, 389-397

Fuchs, S. (1985) Untersuchungen zur quantitativen Abschätzung des Befalls von Bienenvölkern mit Varroa jacobsoni OUD. und zur Verteilung des Parasitenim Bienenvolk. Apidologie 16, 343-368

Fuch, S. (1990) Preference for drone brood cells by Varroa jacobsoni Oud in colonies of Apis mellifera carnica . Apidologie 21, 193-199

Galton, D. (1971) Survey of a thousand years of beekeeping in Russia. Bee Research Association, London

Gilley, D.C., Tarpy, D.R. (2005) Three mechanisms of queen elimination in swarming honey bee colonies. Apidologie 36, 461-474
Gisder, S., Aumeier, P., Genersch, E. (2009) Deformed wing virus: replication and viral load in mites. J. Gen. Virol. 90, 463-467

Goodwin, M., Van Eaton, C. (1999) Elimination of American Foulbrood without the use of drugs. National Beekeepers' Association of New Zealand, Napier, New Zealand

Goodwin, R.M., Taylor, M.A., Mcbrydie, H.M., Cox, H.M. (2006) Drift of Varroa destructor-infested worker honey bees to neighbouring colonies. J. Apic. Res. 45, $155-156$

Greatti, M., Milani, N., Nazzi, F. (1992) Reinfestation of an acaricide-treated apiary by Varroa jacobsoni Oud. Exp. Appl. Acarol. 16, 279-286

Hughes, D.P. (2005) Parasite manipulation: a social context. Behav. Process. 68, 1037-1043

Jay, S.C. (1965) Drifting of honeybees in commercial apiaries. I. Effect of various environmental factors. J. Apic. Res. 4, 167-175

Jay, S.C. (1966a) Drifting of honeybees in commercial apiaries. II. Effect of various factors when hives are arranged in rows. J. Apic. Res. 5, 103-112

Jay, S.C. (1966b) Drifting of honeybees in commercial apiaries. III. Effect of apiary layout. J. Apic. Res. 5, 137-148

Kralj, J., Fuchs, S. (1977) Parasitic Varroa destructor mites influence flight duration and homing ability of infested Apis mellifera foragers. Apidologie 37, 577-587

Martin, S.J. (1994) Ontogenesis of the mite Varroa jacobsoni Oud. in worker brood of the honeybee Apis mellifera L. under natural conditions. Exp. Appl. Ecol. 18, 87-100

Martin, S.J. (1995) Ontogenesis of the mite Varroa jacobsoni Oud. in drone brood of the honeybee Apis mellifera L. under natural conditions. Exp. Appl. Ecol. 19, 199-210

Martin, S.J., Highfield, A.C., Brettell, L., Villalobos, E.M., Budge, G.E., Powell, M., Nikaido, S., Schroeder, D.C. (2012) Global honey bee viral landscape altered by a parasitic mite. Science 336, 1304-1306

Menzel, R., Fuchs, J., Kirbach, A., Lehman, K., Greggers, U. (2012) Navigation and communication in honey bees. In: Honeybee neurobiology and behavior: a tribute to Randolf Menzel. C.G. Galizia, D. Eisenhardt, M. Giurfa(Eds), pp. 103116. Springer, Heidelberg

Pfeiffer, K.J., Crailsheim, J. (1998) Drifting of honeybees. Insectes Soc. 45, 151-167

Rangel, J.S., Seeley, T.D. (2012) Colony fissioning in honey bees: size and significance of the swarm fraction. Insectes Soc. 29, 453-462

Rosenkranz, P., Aumeier, P., Ziegelmann, B. (2010) Biology and control of Varroa destructor. J. Invertebr. Pathol. 103, S96-S119

Sakofski, F., Koeniger, N., Fuchs, S. (1990) Seasonality of honey bee colony invasion by Varroa jacobsoni Oud. Apidologie 21, 547-550 
Schlaepfer, M.A., Runge, M.C., Sherman, P.W. (2002) Ecological and evolutionary traps. Trends Ecol. Evol. 17, 474-480

Seeley, T.D. (2007) Honey bees of the Arnot Forest: a population of feral colonies persisting with Varroa destructor in the northeastern United States. Apidologie 38, 19-20

Seeley, T.D., Tarpy, D.R., Griffin, S.R., Carcione, A, Delaney, D.A. (2015) A survivor population of wild colonies of European honeybees in the northeastern United States: investigating its genetic structure. Apidologie, in press.
Symons, D. (1990) Adaptiveness and adaptation. Ethol. Sociobiol. 11, 427-444

van Dooremalen, C., Gerritsen, L., Cornelissen, G., van der Steen, J.J.M., van Langevelde, F., Blackquière, T. (2012) Winter survival of individual honey bees and honey bee colonies depends on level of Varroa destructor infestation. PLoS ONE 7, e36285

Wehner, R. (1992) Arthropods. In: Papi, F. (ed.) Animal homing, pp. 45-144. Chapman and Hall, London

Wilde, J., Fuchs, S., Bratkowski, J., Siuda, M. (2005) Distribution of Varroa destructor between swarms and colonies. J. Apic. Res. 44, 190-194 